Original research article

\title{
The level of social exclusion of Roma families and the factors that influence it
}

\author{
Alena Kajanová $^{1 *}$, Tomáš Mrhálek ${ }^{2}$ \\ ${ }^{1}$ University of South Bohemia in České Budèjovice, Faculty of Health and Social Sciences, Institute of Social and Special-paedagogical Sciences, \\ České Budějovice, Czech Republic \\ ${ }^{2}$ University of South Bohemia in České Budějovice, Faculty of Education, Department of Pedagogy and Psychology, České Budějovice, Czech Republic
}

\begin{abstract}
This article deals with the assessment of the level of social exclusion of the Roma families in the Czech Republic in relation to sociodemographic factors and the whether their locality was officially labelled as excluded on the basis of the so-called 'Measures of a General Nature'. For the collection of data, we used the 20-item "Scale of social exclusion", which was created by the National Institute for Education and supplemented with basic sociodemographic questions (education, employment, overcrowded household), which we used as independent comparative factors. The group of respondents included Roma families who ethnically identified themselves as Roma. They were selected using quota sampling in the Czech Republic $(N=156)$.

The essential finding in our research is that the label of exclusion of a locality does not correspond with the perception of its population regarding exclusion. It was proven that their sociodemographic factors were not essential for social exclusion besides a father's education. Items focused on the cultural and economic domain of social exclusion varied in sociodemographic factors. There was not a significant relationship between employment and overcrowded household.
\end{abstract}

Keywords: Domain of social exclusion; Level of social exclusion; Roma; Social exclusion

\section{Introduction}

Considering its dynamics and range, social exclusion is viewed as one of the most pressing social problems in the Czech Republic. Although there are many studies regarding individual aspects of social exclusion and analyses of its global range, it is only recently that an exclusion measuring tool has become present.

Social exclusion is seen as a consequence of insufficient opportunities for all who want to participate in building a social life. It causes them to be unable to participate in it and to become isolated from society (Kotýnková, 2000). The unequal approach concerns all life areas, but mostly education, job possibilities, living/housing, availability of medical care and social protection (Navrátil and Šimíková, 2002). Exclusion divides society into those who are "in" and "out" (Mareš, 2006).

Social exclusion has a significant ethnic range - approximately $80 \%$ of the population of the socially excluded localities in the Czech Republic are Roma, and they are also considered the most at-risk group regarding exclusion (GAC, 2006). The causes can be found in structural mechanisms (discrimination, autonomic practice, etc.) as well as individual mechanisms (loss of working habits, addictions, etc.) (Toušek, 2007).
A significant characteristic of exclusion is its multidimensionality (Madanipour, 2003) and dynamism (Byrne, 2005). Usually, there are mutually influencing dimensions of exclusion, such as economic, social, cultural, symbolic, spatial, and political (Littlewood et al., 2000). Economic exclusion involves an insufficient approach to material or financial sources and the mechanisms that distribute these sources (Růžička, 2011). It results in the participation in alternative sources of living (Růžička and Toušek, 2014) and enormous debts (Gojová et al., 2008). A typical manifestation of spatial exclusion is involuntary residential segregation in the so-called excluded localities (Ouředníček, 2005). Blanket screening (Čada et al., 2015) has shown that there are 606 localities with 95-115 thousand inhabitants in the Czech Republic. The social part of exclusion is manifested mainly by lesser mutual solidarity among the excluded. The majority of the society also manifests it (Mareš, 2006). Exclusion from the majority social networks and relationships is also demonstrated. This leads to fewer opportunities for the improvement of social status and may result in the impossibility of leaving the locality (Pierson, 2002). The symbolic part of social exclusion means that the affiliation to the excluded locality stigmatizes its members (Keller, 2014), which leads to further marginalization and discrimination (Kajanová, 2014). Worse opportunities for quality education

\footnotetext{
* Corresponding author: Alena Kajanová, University of South Bohemia in České Budějovice, Faculty of Health and Social Sciences, Institute of Social and Special-paedagogical Sciences, Jírovcova 1347/24, 37004 České Budějovice, Czech Republic; e-mail: kajanova@zsf.jcu.cz; http://doi.org/10.32725/kont.2020.043
} 
is also considered a cultural dimension of social exclusion. This is related to a lower level of education of the socially excluded. It limits their future opportunities (Nekorjak et al., 2011). In the political domain, the socially excluded have fewer opportunities to have their rights met in court due to court costs and legal services (Rákoczyová, 2006). Social exclusion also means limited participation in the political scene and public life (Mareš, 2006). The excluded have decreased opportunities to influence society or their own fates (Mareš 2006), because they seldom participate in elections and discussions regarding their situation (Madanipour, 2003).

The goal of this article is to describe the level of social exclusion of the Roma families in the Czech Republic and the factors that influence it. We mainly focus on the factor of locality, i.e. whether a locality has officially been labelled as socially excluded on the basis of the so-called 'Measures of a General Nature', as well as education, employment, overcrowded household, and primary language in a family.

\section{Materials and methods}

For the data collection, we used the Scale of social exclusion which was created by the National Institute for Education. This was supplemented with basic sociodemographic questions (education, employment, overcrowded household), which we used as independent comparative factors. The Scale of social exclusion was determined for the subjective assessment of exclusion. It is based on 20 items on the Likert scale, where a respondent can achieve $20-80$ points. Exclusion grows with a higher number of points. The questions are focused on the general social status of a family and the view of one's own differences, the assessment of a locality, and child support (mainly regarding school). The questionnaire was administrated as one of the supplementary tools in the complex data collection of the TAČR project and filled in by adults.

The group of respondents included the Roma families who identified themselves as Roma. They were selected using quota sampling in the Czech Republic $(N=156)$. The quotas were presented by regions and by whether a locality was officially labelled as excluded on the basis of the Measures of a General Nature.

The gained data were statistically processed using the SPSS programme and non-parametric tests of Mann-Whitney $U$ test and Kruskal-Wallis $H$ test - with respect to the abnormal distribution of data with an oblique tendency. All results are presented on the level of $p<0.05$.

\section{Results}

We first tested the relationship between the test result of the subjective assessment of social exclusion and legislative labelling of a locality as excluded by the Measures of a General Nature. The result was $p=0.436$. This means that we did not record a statistically significant relationship. For this reason, we tested individual items of the questionnaire. We recorded significance in two questions: Can I afford to buy whatever my child needs for school? $(\mathrm{M} 1=2.64, \mathrm{M} 2=3.07, \mathrm{U}=1,752.5$; $p=0.023)$ and Is reading with children common in our family? ( $11=2.53, \mathrm{M} 2=2.90, \mathrm{U}=1,816, p=0.049)$. This means that the growing level of exclusion causes a lower ability of parents to buy school aids for their children and to read with children.

Another tested item related to the level of exclusion was the primary spoken language in a respondent's household. The hypothesis of the relationship between the language and the score was not confirmed ( $p=0.474)$. The language context was found only in partial items:

Our family's customs are different from the rest of the society: $\mathrm{M} 1=1.85, \mathrm{M} 2=2.31, F=4.544 ; p=0.012$.

Satisfaction with the contemporary life situation of our family: $\mathrm{M} 1=2.37, \mathrm{M} 2=3.25, F=5.437 ; p=0.005$.

We can say that families who speak Romany feel more different from society than families who speak Czech. These families also assess their contemporary life situation as worse.

Considering parents' education, a mother's education is not statistically significant regarding exclusion ( $p=0.801)$. However, a father's education was statistically significant $(F=6.28, p=0.043)$. The connection between significant items in the questionnaire is shown in Table 1. The items are help (There are many people that we can turn to when we need help or arrangements), satisfaction (I am satisfied with our family's contemporary life situation), money (We sometimes have a problem to make ends meet), understanding (Our child has difficulties in making him/herself understood), considerations (The school is sufficiently considerate of our child's specifics and family situation).

The employment of at least one adult family member is not statistically significant regarding the level of exclusion $(p=0.232)$. The individual items of the questionnaire showed significance regarding two questions: 1) Can I afford to buy whatever my child needs for school? ( $\mathrm{U}=1,617.5 ; p=0.022)$; 2) Am I able to support my child to be successful at school? $(\mathrm{U}=1,699.5 ; p=0.010)$.

Overcrowded household was presented objectively. We converted the number of household members into the number of rooms available to the household. In the Czech Republic, the law does not limit the number of household members, so we used an expert assessment, which established the critical value to 3.5 people/room with regard to the cultural specifics of Roma families (Hojsík, 2016). The value of the level of social exclusion was $p=0.061$, thus, the relationship was not confirmed. The relationship was recorded in three items: We sometimes have a problem to make ends meet $(\mathrm{U}=1,158.5 ; p=0.001)$, We find it difficult to arrange important issues at the authorities $(\mathrm{U}=1,374 ; p=0.035)$, and I do not know what to do with the requirements from my child's school and homework $(\mathrm{U}=1,416.5$; $p=0.022$ ).

\section{Discussion}

The essential finding of our research is that labelling a locality as excluded does not correspond with its members' perception of the level of exclusion. It is probably caused by the situation when autonomies set certain criteria for excluding a locality, such as crime rate (Čada et al., 2015). This does not correspond with the subjective view of the members of the excluded locality (Kajanová, 2017). Mareš (2006) states that the excluded have minimum possibilities to affect their own fate. Outsiders often decide about important issues. It is basically a manifestation of the political component of exclusion (Rákoczyová, 2006).

From the point of view of the dominant language, the limitations of this research include imbalanced sample groups. Most respondents primarily spoke Czech. Davidová et al. (2010) state that the Roma in the Czech Republic rarely speak Romany. The so-called ethnolect is more typical, i.e. a mixture of Romany, Czech and possibly other languages. The influence of language was primarily identified in the item of the questionnaire that aimed at the cultural part of exclusion, which is logical, because language is one of the main parts of the cultural capital (Kajanová, 2017). 
Table 1. Significant items of the questionnaire regarding the level of exclusion in the context of parents' education

\begin{tabular}{|c|c|c|c|c|c|c|c|}
\hline & & Education & $N$ & M & SD & $F$ & $p$ \\
\hline \multirow{6}{*}{ MOTHER } & \multirow{3}{*}{ Help } & incomplete & 11 & 3.273 & 1.2721 & \multirow{3}{*}{7.105} & \multirow{3}{*}{0.029} \\
\hline & & PS & 101 & 3.267 & 0.8111 & & \\
\hline & & higher than PS & 14 & 2.429 & 1.1579 & & \\
\hline & \multirow{3}{*}{ Satisfaction } & incomplete & 11 & 3.455 & 1.1282 & \multirow{3}{*}{12.740} & \multirow{3}{*}{0.002} \\
\hline & & PS & 101 & 2.287 & 0.9310 & & \\
\hline & & higher than PS & 15 & 2.733 & 1.0328 & & \\
\hline \multirow{12}{*}{ FATHER } & \multirow{3}{*}{ Money } & incomplete & 5 & 2.000 & 0.7071 & \multirow{3}{*}{7.143} & \multirow{3}{*}{$0.02 \varepsilon$} \\
\hline & & PS & 92 & 3.065 & 0.9470 & & \\
\hline & & higher than PS & 27 & 2.741 & 1.0595 & & \\
\hline & \multirow{3}{*}{ Help } & incomplete & 5 & 2.400 & 1.1402 & \multirow{3}{*}{6.424} & \multirow{3}{*}{$0.04 C$} \\
\hline & & PS & 92 & 3.304 & 0.8611 & & \\
\hline & & higher than PS & 26 & 2.846 & 1.0466 & & \\
\hline & \multirow{3}{*}{ Understanding } & incomplete & 5 & 2.600 & 0.8944 & \multirow{3}{*}{7.341} & \multirow{3}{*}{0.025} \\
\hline & & PS & 92 & 1.815 & 1.2219 & & \\
\hline & & higher than PS & 27 & 1.407 & 1.0099 & & \\
\hline & \multirow{3}{*}{ Considerations } & incomplete & 4 & 2.000 & 1.1547 & \multirow{3}{*}{7.887} & \multirow{3}{*}{0.019} \\
\hline & & PS & 95 & 3.000 & 1.0106 & & \\
\hline & & higher than PS & 27 & 3.481 & 1.0874 & & \\
\hline
\end{tabular}

The subjective assessment of the level of exclusion was related to a father's education and not to a mother's education. It is connected with the labour market. Better education generates a higher opportunity for better employment, which results in a better socioeconomic situation (O'Higgins and Ivanov, 2006). In Roma families, where gender differences are still considerable (Kajanová et al., 2015), men are considered breadwinners and women are often housewives.

The contrast between the objective locality characteristics and the subjective perceptions of its members can be one of the possible problems in the assessment of the effect of the exclusion on an individual. Wesselmann (2019) states that social exclusion affects an individual through their exclusion from the majority. The subjective perception of such an exclusion is the crucial aspect that is connected to the associated negative psychological and social impacts.

\section{Conclusions}

There was an assumption that objective factors, such as low education, unemployment, overcrowded household, or not using Czech language, would increase the level of social exclusion. The results of this research have not confirmed this fact, aside from in several isolated items. All of the significant items referred to cultural and economic parts of exclusion. For this reason, we can say that these two areas are crucial and should be considered more regarding the intervention in the given area.

Regarding the assessment of social exclusion, we would recommend that subjective perceptions of exclusion receive more emphasis in measuring this construct.

\section{Míra sociálního vyloučení romských rodin a faktory, které ji ovlivňují}

\section{Souhrn}

Článek se zabývá zhodnocením míry sociální exkluze u romských rodin v České republice ve vztahu k sociodemografickým faktorům a skutečnosti, zda lokalita byla oficiálně označena jako sociálně exkludovaná na základě tzv. Opatření obecné povahy. Pro sběr dat byla využita dvacetipoložková „Škála sociálního vyloučení vytvořená Národním ústavem pro vzdělávání a doplněná o základní sociodemografické otázky (vzdělání, zaměstnanost, přelidněnost bytu), které jsme použili jako nezávislé komparační faktory. Výzkumný soubor tvořily romské rodiny na základě etnické sebeidentifikace, vybrané kvótním výběrem $\mathrm{v}$ rámci celé České republiky $(N=156)$.

Za zásadní zjištění našeho výzkumu považujeme skutečnost, že nekoresponduje označení lokality jako exkludované obcí a vnímání míry exkluze jejími obyvateli. Prokázalo se, že vlastní sociodemografické faktory nejsou mimo vzdělání otce zásadní pro vnímanou sociální exkluzi, a v rámci jednotlivých položek variovaly se sociodemografickými faktory zejména položky zaměřené na kulturní a ekonomickou dimenzi sociální exkluze. Naopak nebyl zachycen signifikantní vztah se zaměstnaností a přelidněností bytu.

Klíčová slova: dimenze sociální exkluze; míra sociální exkluze; Romové; sociální exkluze 


\section{Conflict of interests}

The authors have no conflict of interests to declare.

\section{Acknowledgements}

This article is an output of the TAČR TL2000187 project: Standardization of WJ IV for Roma children.

\section{References}

1. Byrne D (2005). Social exclusion. Berkshire: Open University Press, 216 p.

2. Čada K, et al. (2015). Analýza sociálně vyloučených lokalit v ČR Praha: GAC, 116 p.

3. Davidová E, et al. (2010). Kvalita života a sociální determinanty zdraví u Romů v České a Slovenské republice. Praha: Triton, $256 \mathrm{p}$.

4. GAC (2006). Analýza sociálně vyloučených lokalit a absorpční kapacity subjektů působících v této oblasti. Praha: GAC. [online] [cit. 2020-08-20]. Available from: https://www.gac.cz/user files/File/nase_prace_vystupy/GAC_MAPA_analyza_SVL_ aAK_CJ.pdf?langSEO=documents\&parentSEO=nase_prace_ vystupy\&midSEO=GAC_MAPA_analyza_SVL_aAK_CJ.pdf

5. Gojová A, et al. (2008). Terénní sociální práce s vybranými cílovými skupinami z hlediska vybraných metod a přístupů sociální práce. In: Janoušková K, Nedělníková D (Eds). Profesní dovednosti terénních sociálních pracovníků. Ostrava: Ostravská univerzita v Ostravě, 401 p.

6. Hojsík M (2016). Indikátory kvality života v oblasti bydlení. Praha: Úřad vlády České republiky, 6 p.

7. Kajanová A (2014). Kvalita života obyvatel sociálně exkludovaných lokalit v Jihočeském kraji. České Budějovice. Habilitační práce. ZSF JU.

8. Kajanová A (2017). Proč selhává sociální práce se sociálně exkludovanými. Praha: Lidové noviny, 72 p.

9. Kajanová A, et al. (2015). (Ne)rovnosti v romských rodinách. Praha: Lidové noviny, 104 p.

10. Keller J (2014). Exkluze jako sociální problém a jako otázka metodologická. Ostravská univerzita v Ostravě: Fakulta sociálních studií, 60 p.

11. Kotýnková M (2000). Rozsah a průběh sociálního vyloučení v české společnosti. Sociální studia 5: 93-103.
12. Littlewood P, Glorieux I, Jönsson I (2000). Social exclusion in Europe: problems and paradigma. Aldershot: Ashgate, 268 p.

13. Madanipour A (2003). Space and Social Exclusion. In: Legates RT, Stout F (Eds). The City Reader. London: Routledge, $211 \mathrm{p}$.

14. Mareš P (2006). Sociální exkluze, sociální inkluze a sociální koheze: diskurz a realita. In: Sirovátka T (Ed.). Sociální vyloučení a sociální politika. Brno: Masarykova univerzita, Výzkumný ústav práce a sociálních věcí, pp. 15-24.

15. Navrátil P, Šimíková I (2002). Hodnocení projektů zaměřených na snižování rizika sociálního vyloučení romské populace. Část I - typologie projektů. Praha: VÚPSV - výzkumné centrum Brno. [online] [cit. 2020-08-20]. Available from: http://praha. vupsv.cz/Fulltext/Romov.pdf

16. Nekorjak M, Souralová A, Vomastková K (2011). Uvíznutí v marginalitě: vzdělávací trh, „romské školy“ a reprodukce sociálně prostorových nerovností. Sociologický časopis 47(4): 657-680.

17. O’Higgins N, Ivanov A (2006). Education and Employment Opportunities for the Roma. Comparative Economic Studies 48: 6-19. DOI: 10.1057/palgrave.ces.8100147.

18. Ouředníček M (2005). Můžeme zjistit míru segregace? In: Sýkora L, Temelová J (Eds). Prevence prostorové segregace. Praha: Univerzita Karlova v Praze, Přírodovědecká fakulta and Ministerstvo pro místní rozvoj, 119 p.

19. Pierson J (2002). Tackling social exclusion. London: Taylor and Francis Library, 251 p.

20. Rákoczyová M (2006). Začleňování na pracovní trh jako součást procesu sociálního začleňování v ČR. Brno: Masarykova univerzita, 80 p.

21. Růžička M (2011). Časoprostorové a infrastrukturní aspekty procesu sociální exkluze. Sociologicky časopis 47(2): 273-295.

22. Růžička M, Toušek L (2014). Sociální exkluze: její prostorové formy a měnící se podoby. In: Šubrt J, et al. (Eds). Soudobá sociologie VI. Praha: Karolinum Press, 402 p.

23. Toušek L (2007). Sociální vyloučení a prostorová segregace (Přehledové studie 07/11). Plzeň: Centrum aplikované antropologie a terénního výzkumu. [online] [cit. 2020-08-20]. Available from: http://www.antropoweb.cz/webzin/achive_old/ webzin_2-3_2007/02_Tousek.pdf

24. Wesselmann ED (2016). Social Exclusion in Everyday Life. In: Riva P, Enck J. (Eds). Social exclusion. New York: Springer, 295 p. 